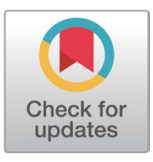

Received: Jan 27, 2021

Revised: Aug 31, 2021

Accepted: Oct 5, 2021

*Corresponding author Dong Yong Kil

Department of Animal Science and Technology, Chung-Ang University,

Anseong 17546, Korea.

Tel: +82-31-670-3028

E-mail: dongyong@cau.ac.kr

Copyright ( $\subset 2021$ Korean Society of Animal Sciences and Technology. This is an Open Access article distributed under the terms of the Creative Commons Attribution Non-Commercial License (http:// creativecommons.org/licenses/bync/4.0/) which permits unrestricted non-commercial use, distribution, and reproduction in any medium, provided the original work is properly cited.

ORCID

Won Jun Choi

https://orcid.org/0000-0003-4000-990X Jong Hyuk Kim

https://orcid.org/0000-0003-0289-2949

Hyun Woo Kim

https://orcid.org/0000-0002-8000-1219

Kwan Eung Kim

https://orcid.org/0000-0002-8392-9864

Dong Yong Kil

https://orcid.org/0000-0002-9297-849X

Competing interests

No potential conflict of interest relevant to this article was reported.

\section{Effects of dietary palm kernel meal and $\beta$-xylanase on productive performance, fatty liver incidence, and excreta characteristics in laying hens}

\author{
Won Jun Choi ${ }^{1}$, Jong Hyuk Kim ${ }^{1}$, Hyun Woo Kim ${ }^{1}$, Kwan Eung Kim² and \\ Dong Yong Kil ${ }^{1 *}$ \\ ${ }^{1}$ Department of Animal Science and Technology, Chung-Ang University, Anseong 17546, Korea \\ ${ }^{2}$ Poultry and Swine Division, Nonghyup Feed, Seoul 05398, Korea
}

\begin{abstract}
The objective of the present experiment was to investigate the effect of dietary palm kernel meal (PKM) and $\beta$-xylanase supplementation on productive performance, egg quality, fatty liver incidence, and excreta characteristics in laying hens. A total of $320 \mathrm{Hy}$-Line Brown laying hens (33 weeks of age) were allotted to 1 of 4 treatments with 8 replicates in a feeding trial. Each replicate consisted of 10 consecutive cages with 1 hen per cage. The corn-soybean meal-based control diet was prepared. Additional diet was prepared by including $10 \%$ of PKM in the control diet with a partial replacement of corn, soybean meal, and animal fat. In addition, $0.025 \% \beta$-xylanase was supplemented at the expense of celite to those 2 diets to produce 4 treatment diets in a $2 \times 2$ factorial arrangement. All hens were provided the diet and water ad libitum for 8 weeks. Results indicated no significant interactions between inclusion of dietary PKM and $\beta$-xylanase for all measurements; therefore, the main effects were mainly discussed. Hens fed diets containing $10 \%$ PKM had greater $(p<0.05)$ feed intake and yolk color than those fed diets containing no PKM. However, dietary PKM did not influence fatty liver incidence and excreta characteristics. Dietary $\beta$-xylanase supplementation had no effects on all measurements, regardless of inclusion of PKM. In conclusion, PKM can be a potential feed ingredient for laying hens at the inclusion of $10 \%$ in the diet. It appears that dietary $\beta$-xylanase used in the current experiment has little effect on layer productivity, regardless of inclusion of $10 \%$ PKM in the diet.
\end{abstract}

Keywords: $\beta$-xylanase, Egg quality, Excreta characteristics, Laying hen, Palm kernel meal, Performance

\section{INTRODUCTION}

Palm kernel meal (PKM) is a by-product of palm kernel during palm oil extraction, which is mostly produced in Southeast Asia countries (e.g., Indonesia and Malaysia). Because of its nutritional values 
Funding sources

This research was supported by Nonghyup

Feed, Seoul. This research was also supported by the Chung-Ang University Graduate Research Scholarship (Academic Scholarship for College of Biotechnology and Natural Resources) in 2021.

Acknowledgements

Not applicable.

Availability of data and material Upon reasonable request, the datasets of this study can be available from the corresponding author.

\section{Authors' contributions}

Conceptualization: Choi WJ, Kim KE, Kil DY. Data curation: Choi WJ, Kim JH, Kim HW. Formal analysis: Choi WJ, Kim HW, Kim KE, Kil DY.

Methodology: Choi WJ, Kim JH, Kim HW, Kil DY.

Software: Choi WJ, Kim JH.

Validation: Kim JH, Kim HW, Kim KE.

Investigation: Choi WJ, Kim JH, Kim HW, Kil DY.

Writing - original draft: Choi WJ, Kim JH. Writing - review \& editing: Kim JH, Kim HW, Kim KE, Kil DY.

Ethics approval and consent to participate The protocol for the current experiment was reviewed and approved by the Institutional Animal Care and Use Committee at ChungAng University (IACUC No. 2020-00042). and low production cost, $\mathrm{PKM}$ has been considered an economical ingredient for poultry diets [1]. It has been reported that inclusion of PKM up to $40 \%$ in poultry diets has no adverse effects on productive performance $[2,3]$. However, poultry nutritionists often hesitate to use the large amounts of PKM in diets because of its adverse properties such as dark color and poor essential amino acid profiles. In addition, PKM contains the relatively high amounts of nonstarch polysaccharides (NSP), which is well-known as an antinutritional factor due to impairment in nutrient digestion and absorption in the gastrointestinal tract of animals $[4,5]$. Therefore, dietary supplementation of NSP-degrading enzymes (NSPase) is widely used in the feed industry when PKM is included in the diet. In particular, dietary $\beta$-mannanase is often supplemented to diets containing PKM because $\beta$-mannan is the major NSP in PKM [6]. It has been reported that dietary supplementation of $\beta$-mannanase in diets containing PKM improved productive performance of broiler chickens and laying hens $[7,8]$. Dietary $\beta$-xylanase may also be considered a potential NSPase in diets containing PKM because xylan is also present at the high amount in PKM [6]. Supplementation of $\beta$-xylanase in diets containing PKM was reported to improve growth performance of broiler chickens [9]. However, there is currently little information regarding the interactive effects of dietary PKM and $\beta$-xylanase supplementation in laying hens.

Therefore, the objectives of the present experiment were to investigate the effects of dietary PKM and $\beta$-xylanase supplementation on productive performance, egg quality, fatty liver incidence, and excreta characteristics in laying hens.

\section{MATERIALS AND METHODS}

\section{Animals, experimental design, and diets}

The protocol for the current experiment was reviewed and approved by the Institutional Animal Care and Use Committee at Chung-Ang University (IACUC No. 2020-00042). A total of 320 Hy-Line Brown laying hens (Icheon, Korea) with 33 weeks of age were allotted to 1 of 4 dietary treatments with 8 replicates in a feeding trial. Each replicate consisted of 10 consecutive cages with 1 hen per cage $(37 \mathrm{~cm} \times 30 \mathrm{~cm} \times 40 \mathrm{~cm}=$ width $\times$ length $\times$ height $)$. The experiment was conducted in a completely randomized design with a $2 \times 2$ factorial arrangement with dietary supplementation of PKM and $\beta$-xylanase. The control diet was formulated mainly with corn and soybean meal. Additional diet was prepared with the inclusion of 10\% PKM in the control diet with a partial replacement of corn and soybean meal. The commercial PKM was used in this experiment and nutritional compositions of PKM is presented in Table 1. In addition, $0.025 \%$ $\beta$-xylanase (Econase ${ }^{\circledR} \mathrm{XT}$, declared activity of 4,000,000 unit/g, AB Vista, Marlborough, UK) was supplemented to 2 of 4 treatment diets by replacing the same amounts of celite in treatment diets. All nutrients and energy in the experimental diets were formulated to meet or exceed recommendations of the Hy-Line International [10] (Table 2). The diets and water were provided ad libitum for 8 weeks. The cages were placed in an environmentally-controlled laying house with $16 \mathrm{~h}$ of lighting and $8 \mathrm{~h}$ of darkness. Temperature and humidity were maintained at $23 \pm 3{ }^{\circ} \mathrm{C}$ and $64 \pm 9 \%$ throughout the entire experiment, respectively.

\section{Data and sample collection and chemical analysis}

The color of diets was measured using a colorimeter (model CR-10, Konica Minolta Optics, Tokyo, Japan) to assess the color change due to the inclusion of 10\% PKM.

Hen-day egg production, egg weight (EW), and broken and shell-less egg production rate were recorded daily. Feed intake (FI) and feed conversion ratio (FCR) were recorded at 4-week intervals. Egg mass (EM) was calculated based on hen-day egg production and EW. The data for productive 
Table 1. Analyzed and reported nutrient concentrations of palm kernel meal (PKM)

\begin{tabular}{lcc}
\hline \multicolumn{1}{c}{ Item } & Analyzed value & Reported value $^{1)}$ \\
\hline Gross energy (kcal/kg) & 4,379 & 4,378 \\
CP (\%) & 13.4 & 15.2 \\
Dry matter (\%) & 93.1 & 91.2 \\
Crude ash (\%) & 3.8 & 4.3 \\
Ether extract (\%) & 7.2 & 8.4 \\
Neutral detergent fiber (\%) & 70.9 & 66.6 \\
Acid detergent fiber (\%) & 40.9 & 40.9 \\
Amino acid (\%) & & \\
Arginine & 1.60 & 1.93 \\
Histidine & 0.25 & 0.32 \\
Isoleucine & 0.35 & 0.53 \\
Leucine & 0.78 & 0.94 \\
Lysine & 0.38 & 0.44 \\
Methionine & 0.27 & 0.27 \\
Methionine + cysteine & 0.45 & 0.46 \\
Phenylalanine & 0.69 & 0.59 \\
Threonine & 0.45 & 0.47 \\
Valine & 0.66 & 0.76 \\
Alanine & 0.49 & 0.61 \\
Aspartic acid & 1.07 & 1.20 \\
Glutamic acid & 2.51 & 2.83 \\
Glycine & 0.60 & 0.69 \\
Proline & 0.44 & 0.47 \\
Serine & 0.63 & 0.65 \\
Tyrosine & 0.30 & 0.38 \\
\hline Adoptedfom Heyze & \\
\hline
\end{tabular}

${ }^{11}$ Adopted from Heuzé et al. with CC-BY-NC [17].

performance were summarized for 8 weeks of the feeding trial.

Egg quality was analyzed with 12 eggs per replicate, which were randomly collected at the end of the experiment. Eggshell color was determined by the method described by Kim et al. [11]. In short, eggshell color was determined using the eggshell color fan (Samyangsa, Wonju, Korea) with different scales from 1 to 15 ( 1 = light white; 15 = dark brown). The CIE color scale for L*, a*, and b" were also measured using a colorimeter (model CR-10, Konica Minolta Optics). Egg yolk color, haugh unit, and eggshell strength were analyzed using digital egg tester (DET-6000, Nabel, Tokyo, Japan) as reported previously [12].

At the end of experiment, the individual body weight (BW) of all laying hens was recorded. One hen with the closest average BW per replicate was chosen and euthanized by $\mathrm{CO}_{2}$ asphyxiation. For a measure of fatty liver incidence, images of the liver attached on the body were pictured to determine the subjective fatty liver score on a scale from 1 to $5(1=$ dark red; $5=$ yellowish red $)$ [13]. In addition, the objective CIE color scale for the $\mathrm{L}^{*}, \mathrm{a}^{*}$, and $\mathrm{b}^{*}$ were also determined using a colorimeter (model CR-10, Konica Minolta Optics). Afterward, the liver was detached, weighed, and collected for measuring total lipid concentrations [14].

At the end of the feeding trial (41 weeks of age), 24 laying hens (i.e., 6 hens per treatment) were selected and randomly placed in metabolic cages with one bird per cage $(35.2 \mathrm{~cm} \times 45.0 \mathrm{~cm} \times 55.3$ $\mathrm{cm}=$ width $\times$ length $\times$ height) to measure excreta characteristics based on the method described by 
Table 2. Ingredient composition and nutrient concentration of the experimental diets

\begin{tabular}{|c|c|c|}
\hline \multirow{2}{*}{ Item } & \multicolumn{2}{|c|}{ Inclusion levels of palm kernel meal (\%) } \\
\hline & 0 & 10 \\
\hline Ingredients (\%) & 100.00 & 100.00 \\
\hline Corn & 56.35 & 45.57 \\
\hline Soybean meal $(46 \% \mathrm{CP})$ & 20.08 & 17.36 \\
\hline Corn gluten meal (58\% CP) & 4.02 & 4.50 \\
\hline Palm kernel meal & 0.00 & 10.00 \\
\hline DDGS & 7.00 & 7.00 \\
\hline Animal fat & 1.00 & 3.89 \\
\hline L-Lysine $(78 \%)$ & 0.16 & 0.24 \\
\hline DL-Methionine (98\%) & 0.12 & 0.14 \\
\hline L-Threonine (98\%) & 0.00 & 0.03 \\
\hline Choline chloride & 0.04 & 0.07 \\
\hline Tricalcium phosphate & 0.86 & 0.90 \\
\hline Limestone & 9.66 & 9.59 \\
\hline Salt & 0.25 & 0.25 \\
\hline Sodium bicarbonate & 0.12 & 0.12 \\
\hline Vitamin premix ${ }^{1)}$ & 0.12 & 0.12 \\
\hline Mineral premix $x^{2)}$ & 0.12 & 0.12 \\
\hline Phytase & 0.05 & 0.05 \\
\hline Celite $^{3)}$ & 0.05 & 0.05 \\
\hline \multicolumn{3}{|c|}{ Calculated energy and nutrient content } \\
\hline $\mathrm{AME}_{\mathrm{n}}(\mathrm{kcal} / \mathrm{kg})$ & 2,692 & 2,695 \\
\hline $\mathrm{CP}(\%)$ & 18.00 & 18.00 \\
\hline \multicolumn{3}{|l|}{ Amino acid (\%) } \\
\hline Lysine & 0.82 & 0.82 \\
\hline Methionine + cysteine & 0.67 & 0.67 \\
\hline Methionine & 0.40 & 0.42 \\
\hline Threonine & 0.57 & 0.57 \\
\hline Tryptophan & 0.16 & 0.15 \\
\hline Calcium (\%) & 4.00 & 4.00 \\
\hline Available phosphorus (\%) & 0.35 & 0.35 \\
\hline \multicolumn{3}{|c|}{ Analyzed energy and nutrient content } \\
\hline Gross energy (kcal/kg) & 3,622 & 3,742 \\
\hline $\mathrm{CP}(\%)$ & 18.4 & 15.7 \\
\hline Dry matter (\%) & 90.6 & 91.7 \\
\hline Crude ash (\%) & 11.0 & 10.9 \\
\hline Ether extract (\%) & 4.1 & 6.9 \\
\hline Neutral detergent fiber (\%) & 11.7 & 16.0 \\
\hline Acid detergent fiber (\%) & 4.8 & 6.5 \\
\hline \multicolumn{3}{|l|}{ Feed color (CIE value) } \\
\hline$L^{*}$ & 63.4 & 54.0 \\
\hline$a^{*}$ & 7.7 & 6.7 \\
\hline$b^{*}$ & 32.7 & 27.3 \\
\hline
\end{tabular}

1)Provided per kg of the complete diet: vitamin A, 10,000 IU (retinyl acetate); vitamin $\mathrm{D}_{3}$, 4,500 IU; vitamin $\mathrm{K}_{3}, 3.0 \mathrm{mg}$ (menadione dimethpyrimidinol); vitamin $\mathrm{B}_{1}, 2.50 \mathrm{mg}$; vitamin $\mathrm{B}_{2}, 6.50 \mathrm{mg}$; vitamin $\mathrm{B}_{6}, 3.20 \mathrm{mg}$; vitamin $\mathrm{B}_{12}, 18.0 \mu \mathrm{g}$; biotin, $180 \mu \mathrm{\mu g}$; folic acid, $1.9 \mathrm{mg}$; niacin, $60 \mathrm{mg}$.

${ }^{2)}$ Provided per kg of the complete diet: cobalt, 1,200 $\mu \mathrm{g}\left(\mathrm{CoSO}_{4}\right)$; copper, $19.0 \mathrm{mg}\left(\mathrm{CuSO}_{4}\right)$; iron, $72 \mathrm{mg}\left(\mathrm{FeSO}_{4}\right)$; iodine, $1.5 \mathrm{mg}$ $\left(\mathrm{Ca}\left[\mathrm{IO}_{3}\right]_{2}\right)$; manganese, $144.0 \mathrm{mg}(\mathrm{MnO})$; selenium, $360 \mu \mathrm{g}\left(\mathrm{Na}_{2} \mathrm{SeO}_{3}\right)$; zinc, $120 \mathrm{mg}\left(\mathrm{ZnSO}_{4}\right)$.

${ }^{3)} 0.025 \%$-xylanase (Econase ${ }^{\circledR} \mathrm{XT}$, declared activity of 4,000,000 unit/g, AB Vista, Marlborough, UK) was supplemented to treatment diets by replacing the same amounts of celite.

$\mathrm{CP}$, crude protein; DDGS, dried distiller's grains with solubles; $\mathrm{AME}_{n}$, nitrogen-corrected apparent metabolizable energy. 
Ogunji et al. [15] (Table 6). The excreta moisture score was visually measured on a scale from 1 to 4 ( 1 = normal dry droppings and coning; 2 = slightly loose droppings, some coning but no free water; 3 = loose droppings with slight coning and some free water; 4 = extremely loose droppings with no coning and large amounts of free water). Excreta samples were also collected daily from each cage to analyze the actual moisture concentrations. Excreta moisture concentrations were determined using drying oven at $100^{\circ} \mathrm{C}$ for $12 \mathrm{~h} \mathrm{[16].}$

The samples for PKM and experimental diets were dried and finely ground for analyzing the concentrations of crude protein (CP; method 990.03), dry matter (DM; method 930.15), crude ash (method 942.05), ether extract (method 2003.05), neutral detergent fiber (method 2002.04), and acid detergent fiber (method 973.18) as followed by the AOAC methods [14]. In addition, the concentrations of amino acids in PKM were analyzed by the AOAC (method 982.30) [14]. The concentrations of gross energy in the samples were analyzed using a bomb calorimetry (Model 6400; Parr Instruments, Moline, IL, USA) with benzoic acid used as the calibration standard [14].

\section{Statistical analysis}

All data were analyzed by 2-way ANOVA (analysis of variance) in a completely randomized design with the GLM procedure of SAS (SAS Institute, Cary, NC, USA). The replicate was used as an experimental unit. Outliers were checked using the UNIVARIATE procedure of SAS. The model included the effects of dietary PKM, $\beta$-xylanase supplementation, and their interaction as fixed variables. However, there were no significant interactions for all measurements. The MEANS procedure was used to calculate treatment means. Significance for statistical test was set at $p<0.05$.

\section{RESULTS AND DISCUSSION}

The concentrations of CP in PKM (13.4\%) were slightly less than previously reported values (15.2\%) [17], which may be the reason why analyzed CP concentrations in diets were decreased with 10\% inclusion levels of PKM (Table 2), although treatment diets were formulated to maintain equivalent $\mathrm{CP}$ concentrations among treatment diets. However, the concentrations of other nutrients in PKM were similar to those values reported previously [17]. Therefore, the PKM used in the current experiment can be considered the typical and representative PKM used in the commercial animal diet. Moreover, the color of diets containing 10\% PKM was darker (i.e., 14.8\% less lightness) than the color of diets containing no PKM, which is likely due to the dark color of PKM.

No significant interactions for all measurements were observed between dietary PKM and $\beta$-xylanase supplementation. This result was unexpected because inclusion of PKM in diets increases the amounts of viscous NSP, which is known to be detrimental on layer production; therefore, dietary $\beta$-xylanase supplementation would alleviate the negative effects. The possible reason may be that the amount of xylan in PKM is relatively low enough to exert significant effect of dietary $\beta$-xylanase [6]. Aderibigbe et al. [18] also reported no positive effects of dietary supplementation of $\beta$-xylanase in diets containing PKM on growth performance of broiler chickens. In addition, the current inclusion levels of PKM (i.e., 10\%) is insufficient to induce a significant antinutritional effect.

Inclusion of $10 \% \mathrm{PKM}$ in layer diets did not affect productive performance, except that hens fed diets containing 10\% PKM had greater $(p<0.05)$ FI than those fed diets containing no PKM (Table 3). Likewise, dietary supplementation of $0.025 \% \beta$-xylanase had no effects on productive performance of laying hens. This result agreed with previous experiments reporting no significant effects of inclusion of 10\% PKM in diets on productive performance of laying hens [1,2]. However, 
Table 3. Effect of dietary palm kernel meal (PKM) and $\beta$-xylanase supplementation on productive performance of laying hens

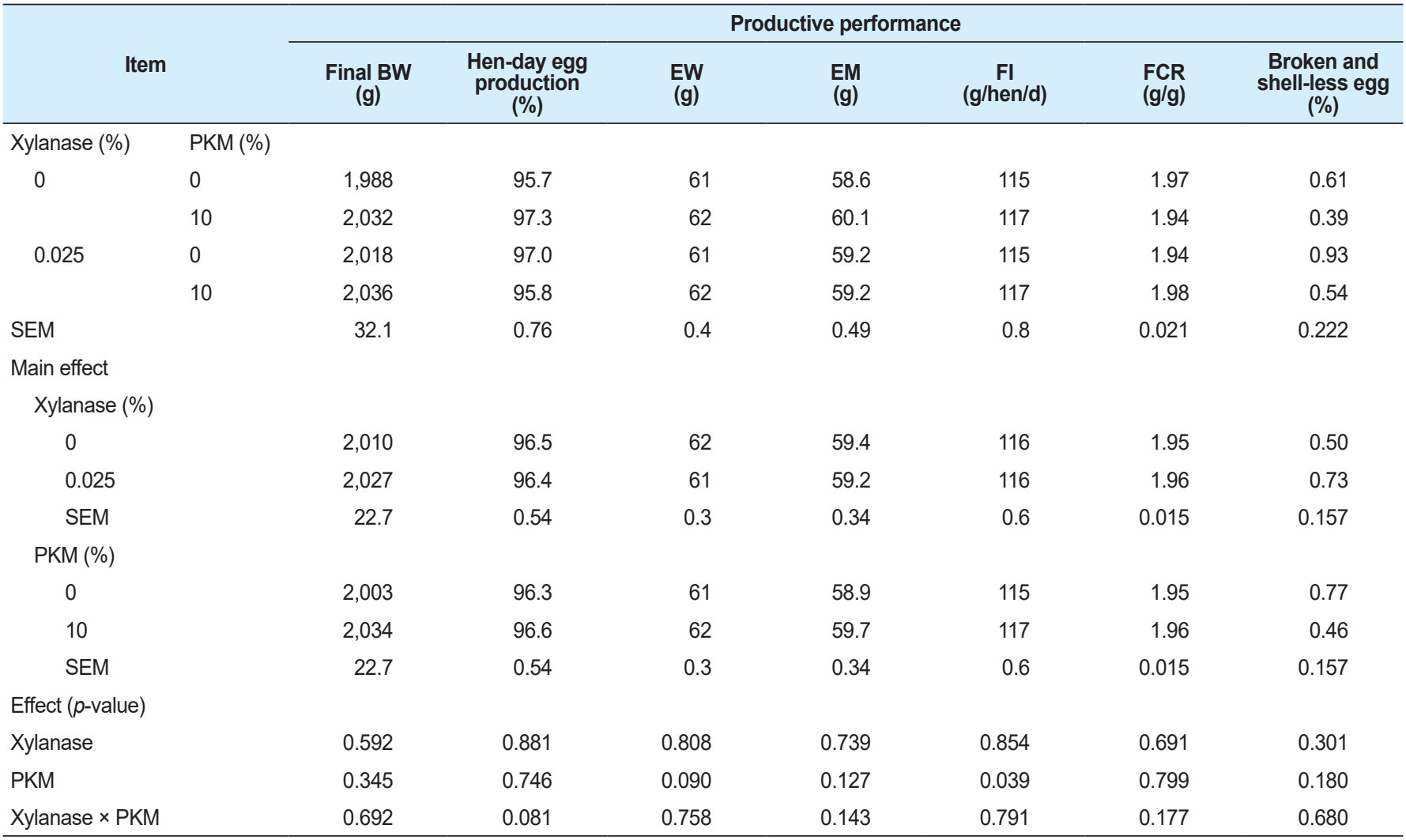

$\mathrm{BW}$, body weight; $\mathrm{EW}$, egg weight; $\mathrm{EM}$, egg mass; $\mathrm{Fl}$, feed intake; $\mathrm{FCR}$, feed conversion ratio.

increased FI was observed by feeding diets containing 10\% PKM to laying hens in this experiment. The reason for this observation may be related to high amounts of fiber in PKM. Poultry has a tendency to consume diets until the energy and nutrient requirements are satisfied [19]. Dietary fiber is an antinutritional factor that is associated with decreased available energy and nutrients in diets, and therefore, increases in dietary fiber are often related to increased FI, which is required to compensate for the decreased intake of available energy and nutrients $[4,20]$. No differences in other productive performance such as hen-day egg production, EW, EM, and FCR also supported that hens fed diets containing 10\% PKM had available energy and nutrient that are similar to those fed diets containing no PKM. Dietary $\beta$-xylanase supplementation has been reported to ameliorate antinutritional effects of NSP such as xylan in PKM [4]. However, all measurements for productive performance were not influenced by dietary $\beta$-xylanase supplementation in the current experiment. This observation may be explained by the fact that antinutritional effects of xylan are not noticeable when 10\% PKM is included in diets. Perez et al. [2] and Abdollahi [7] also reported that 10\% PKM in the diet had no antinutritional effects on productive performance of laying hens.

There were no differences in all egg quality measurements, except for egg yolk color, by feeding diets containing 10\% PKM to laying hens (Table 4). For egg yolk color, hens fed diets containing $10 \%$ PKM had greater $(p<0.05)$ yolk color than those fed diets containing no PKM. This result agreed with previous experiments reporting that feeding diets containing PKM or fermented PKM to laying hens increased egg yolk color score [21,22]. The reason is likely that PKM contains high amounts of carotenoids, which are the main chemical compounds responsible for the yellow coloration of egg yolk $[22,23]$. However, egg quality was not affected by dietary $\beta$-xylanase supplementation, regardless of inclusion of $10 \%$ PKM in diets [1]. 
Table 4. Effect of dietary palm kernel meal (PKM) and $\beta$-xylanase supplementation on egg quality of laying hens

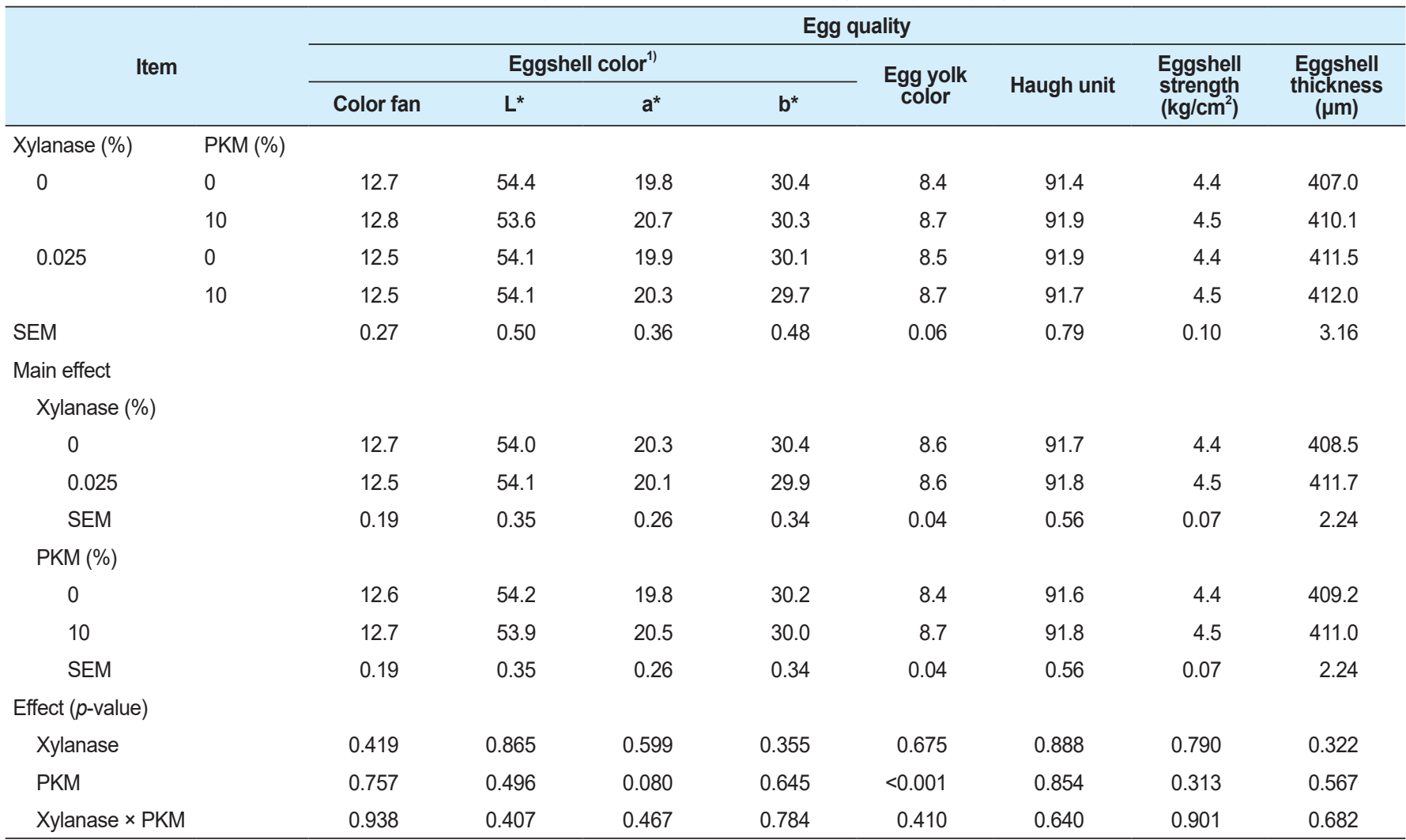

${ }^{1}$ Eggshell color was measured by the color fan scale and CIE [11].

Neither inclusion of $10 \%$ PKM or $0.025 \% \beta$-xylanase supplementation in diets influenced visual inspection scores of fatty liver, CIE colors, and lipid concentrations in the liver (Table 5). Fatty liver syndrome (FLS) or fatty live hemorrhagic syndrome (FLHS) frequently occurs in laying hens, which is often associated with considerable economical losses in layer production [24]. In particular, FLS or FLHS prevails for laying hens that are raised in confined cages. The primary etiology includes dietary nutrients, environment, hormones, and genetic factors [13,25]. It has been reported that feeding high amounts of dietary fiber to laying hens may decrease the progress of fatty liver development by regulating lipid transport from or to the liver [26]. In addition, Akiba and Matsumoto [27] reported that dietary fiber increases lipoproetin lipase activity and reduces hormone-sensitive lipase activity, which was suggested as the reason for decreased liver lipid deposition in chicks. This is the reason why we hypothesized that inclusion of 10\% PKM in diets may decrease the characteristics of fatty liver development; however, no such beneficial effect was observed in this experiment. This lack of response may be due to the fact that animals (e.g., age of hens) and environment (e.g., dietary compositions and stocking density) in the current experiments may not be enough to increase susceptibility to fatty liver development in laying hens.

Visual excreta scores and moisture concentrations were not affected by inclusion of 10\% PKM in diets (Table 6). In addition, dietary $\beta$-xylanase supplementation did not influence on the excreta scores and moisture concentrations, regardless of PKM in diets. Watery excreta is highly associated with increasing production of dirty eggs, which are easily contaminated by microbes, jeopardizing the egg safety [28]. Jimenez-Moreno et al. [29] reported that excreta moisture concentrations were positively correlated with fiber concentrations in poultry diets. However, although inclusion of 10\% PKM increased fiber concentrations in diets, excreta score and moisture concentrations 
Table 5. Effect of dietary palm kernel meal (PKM) and $\beta$-xylanase supplementation on fatty liver incidence of laying hens

\begin{tabular}{|c|c|c|c|c|c|c|}
\hline \multirow{3}{*}{ Item } & & \multicolumn{5}{|c|}{ Fatty liver } \\
\hline & & \multicolumn{4}{|c|}{ Liver color $^{1)}$} & \multirow{2}{*}{$\begin{array}{l}\text { Lipid concen- } \\
\text { tration }(\%)\end{array}$} \\
\hline & & Score & $L^{*}$ & $a^{*}$ & $\mathbf{b}^{*}$ & \\
\hline Xylanase (\%) & PKM (\%) & & & & & \\
\hline \multirow[t]{2}{*}{0} & 0 & 2.1 & 32.5 & 22.1 & 12.4 & 34.7 \\
\hline & 10 & 1.9 & 33.3 & 18.9 & 13.2 & 33.0 \\
\hline \multirow[t]{2}{*}{0.025} & 0 & 2.9 & 34.0 & 20.1 & 15.2 & 32.9 \\
\hline & 10 & 2.4 & 32.4 & 21.1 & 12.0 & 33.9 \\
\hline SEM & & 0.36 & 1.73 & 1.01 & 1.93 & 1.73 \\
\hline \multicolumn{7}{|l|}{ Main effect } \\
\hline \multicolumn{7}{|l|}{ Xylanase (\%) } \\
\hline 0 & & 2.0 & 32.9 & 20.5 & 12.8 & 33.8 \\
\hline 0.025 & & 2.7 & 33.2 & 20.6 & 13.6 & 33.5 \\
\hline SEM & & 0.25 & 1.23 & 0.71 & 1.36 & 1.22 \\
\hline \multicolumn{7}{|l|}{ PKM (\%) } \\
\hline 0 & & 2.5 & 33.3 & 21.1 & 13.8 & 33.8 \\
\hline 10 & & 2.2 & 32.8 & 20.0 & 12.6 & 33.5 \\
\hline SEM & & 0.25 & 1.23 & 0.71 & 1.36 & 1.22 \\
\hline \multicolumn{7}{|l|}{ Effect ( $p$-value) } \\
\hline Xylanase & & 0.077 & 0.872 & 0.951 & 0.693 & 0.807 \\
\hline PKM & & 0.345 & 0.800 & 0.273 & 0.550 & 0.854 \\
\hline Xylanase $\times$ PKM & & 0.604 & 0.488 & 0.051 & 0.320 & 0.451 \\
\hline
\end{tabular}

${ }^{1)}$ Liver score was measured by the scale and $\mathrm{CIE}[13,23]$.

Table 6. Effect of dietary palm kernel meal (PKM) and $\beta$-xylanase supplementation on excreta characteristics of laying hens

\begin{tabular}{clcc}
\hline & \multirow{2}{*}{ Item } & \multicolumn{2}{c}{ Excreta charateristics } \\
\cline { 2 - 4 } Xylanase (\%) & PKM (\%) & Score ${ }^{1)}$ & Moisture (\%) \\
0 & 0 & 1.9 & 70.5 \\
0.025 & 10 & 2.0 & 70.2 \\
& 0 & 2.0 & 73.0 \\
SEM & 10 & 2.2 & 71.8 \\
Main effect & & 0.10 & 1.22 \\
Xylanase (\%) & & & \\
0 & & & \\
0.025 & & 1.9 & 70.3 \\
SEM & & 2.1 & 72.4 \\
PKM (\%) & & 0.07 & 0.86 \\
0 & & & \\
10 & & 1.9 & 71.7 \\
SEM & 2.1 & 71.0 \\
Effect (p-value) & 0.07 & 0.86 \\
Xylanase & & 0.107 \\
PKM & & & 0.552 \\
Xylanase $\times$ PKM & & 0.115 & 0.697 \\
\hline
\end{tabular}

${ }^{1)}$ Excreta moisture score was measured by the scale [15]. 
were not influenced by inclusion of $10.0 \%$ PKM in diets. It has been reported that viscous excreta induced by soluble NSP may also increase excreta moisture concentrations [30]. Thus, we expected that dietary $\beta$-xylanase supplementation may ameliorate excreta moisture concentrations when PKM is included in diets, but we failed to find the interactive effect. No change in excreta score and moisture concentrations by feeding diets containing $10 \%$ PKM appears to explain why dietary $\beta$-xylanase supplementation had no effects on excreta score and moisture concentrations.

In conclusion, PKM can be a potential feed ingredient for laying hens at the inclusion of $10 \%$ in the diet. It appears that dietary $\beta$-xylanase used in the current experiment has little effect on layer productivity, regardless of inclusion of 10\% PKM in the diet. Inclusion of 10\% PKM in diets is effective in improving egg yolk color of laying hens. In addition, inclusion of 10\% PKM in layer diets does not increase the dirty egg production by increasing watery excreta production.

\section{REFERENCES}

1. Akpodiete OJ. Performance response and egg qualities of laying birds fed enzyme supplemented palm kernel cake (PKC) based diets. Anim Res Int. 2008;5:819-22. https://doi.org/10.4314/ ari.v5i1.48721

2. Perez JF, Gernat AG, Murillo JG. The effect of different levels of palm kernel meal in layer diets. Poult Sci. 2000;79:77-9. https://doi.org/10.1093/ps/79.1.77

3. Onwudike OC. Palm kernel meal as a feed for poultry. 4. Use of palm kernel meal by laying birds. Anim Feed Sci Technol. 1988;20:279-86. https://doi.org/10.1016/0377-8401(88)90002-8

4. Sundu B, Dingle JG. Use of enzymes to improve the nutritional value of palm kernel meal and copra meal. Poster session presented at Queensland Poultry Science Symposium 2003; 2003 July 24; Queensland, Australia.

5. Liu S, Ma C, Liu L, Ning D, Liu Y, Dong B. $\beta$-Xylosidase and $\beta$-mannosidase in combination improved growth performance and altered microbial profiles in weanling pigs fed a corn-soybean meal-based diet. Asian-Australas J Anim Sci. 2019;32:1734-44. https://doi.org/10.5713/ ajas.18.0873

6. Düsterhöft EM, Voragen AGJ, Engels FM. Non-starch polysaccharides from sunflower (Helianthus annuus) meal and palm kernel (Elaeis guineenis) meal - preparation of cell wall material and extraction of polysaccharide fractions. J Sci Food Agric. 1991;55:411-22. https://doi. org/10.1002/jsfa.2740550309

7. Abdollahi MR, Hosking BJ, Ning D, Ravindran V. Influence of palm kernel meal inclusion and exogenous enzyme supplementation on growth performance, energy utilization, and nutrient digestibility in young broilers. Asian-Australas J Anim Sci. 2016;29:539-48. https://doi. org/10.5713/ajas.15.0224

8. Lee JY, Kim SY, Lee JH, Lee JH, Ohh SJ. Effect of dietary $\beta$-mannanase supplementation and palm kernel meal inclusion on laying performance and egg quality in 73 weeks old hens.J Anim Sci Technol.2013;55:115-22. https://doi.org/10.5187/JAST.2013.55.2.115

9. Sharmila A, Azhar K, Hezmee MN, Samsudin AA. Effect of xylanase and cellulase supplementation on growth performance, volatile fatty acids and caecal bacteria of broiler chickens fed with palm kernel meal-based diet.J Anim Poult Sci. 2014;3:19-28.

10. Hy-Line International. Hy-Line Brown Commercial layers-Austrailia: management guide [Internet]. Hy-Line International. 2018 [cited 2021 Aug 12]. https://www.hyline.com/filesimages/Hy-Line-Products/Hy-Line-Product-PDFs/Brown/BRN\%20COM\%20AUS.pdf

11. Kim JH, Pitargue FM, Jung H, Han GP, Choi HS, Kil DY. Effect of superdosing phytase on productive performance and egg quality in laying hens. Asian-Australas J Anim Sci. 
2017;30:994-8. https://doi.org/10.5713/ajas.17.0149

12. Azzam MMM, Dong XY, Dai L, Zou XT. Effect of excess dietary L-valine on laying hen performance, egg quality, serum free amino acids, immune function and antioxidant enzyme activity. Br Poult Sci. 2015;56:72-8. https://doi.org/10.1080/00071668.2014.989487

13. Choi YI, Ahn HJ, Lee BK, Oh ST, An BK, Kang CW. Nutritional and hormonal induction of fatty liver syndrome and effects of dietary lipotropic factors in egg-type male chicks. Asian-Australas J Anim Sci. 2012;25:1145-52. https://doi.org/10.5713/ajas.2011.11418

14. AOAC [Association of Official Analytical Chemists] International. Official methods of analysis of AOAC International. 18th ed. Gaithersburg, MD: AOAC International; 2006.

15. Ogunji PA, Brewer RN, Roland Sr. DA, Caldwell D. Effect of dietary sodium chloride, protein, and strain difference upon water consumption and fecal moisture content of broiler breeder males. Poult Sci. 1983;62:2497-500. https://doi.org/10.3382/ps.0622497

16. Kim JH, Choi HS, Goo D, Park GH, Han GP, Delos Reyes JB, et al. Effect of dietary melamine concentrations on growth performance, excreta characteristics, plasma measurements, and melamine residue in the tissue of male and female broiler chickens. Poult Sci. 2019;98:3204-11. https://doi.org/10.3382/ps/pez050

17. Heuzé V, Tran G, Sauvant D, Noblet J, Renaudeau D, Bastianelli D, et al. Palm kernel meal [Internet]. Feedipedia. 2016 [cited 2021 Aug 12]. https://www.feedipedia.org/node/43

18. Aderibigbe TA, Atteh JO, Alli OI, Okukpe KM. Effects of xylanase enzyme supplemented palm kernel cake (PKC) diet on performance and nutrient retention of broiler chickens. Niger J Anim Sci. 2018;20:402-13.

19. Ferket PR, Gernat AG. Factors that affect feed intake of meat birds: a review. Int J Poult Sci. 2006;5:905-11. https://doi.org/10.3923/ijps.2006.905.911

20. Chong $\mathrm{CH}$, Zulkifli I, Blair R. Effects of dietary inclusion of palm kernel cake and palm oil, and enzyme supplementation on performance of laying hens. Asian-Australas J Anim Sci. 2008;21:1053-8. https://doi.org/10.5713/ajas.2008.70581

21. Zanu HK, Abangiba J, Arthur-Badoo W, Akparibo AD, Sam R. Laying chickens' response to various levels of palm kernel cake in diets. Int J Livest Prod. 2012;3:12-6. https://doi. org/10.5897/IJLP11.022

22. Sinurat AP, Purwadaria T, Ketaren PP, Pasaribu T. Substitutions of soybean meal with enriched palm kernel meal in laying hens diet. J Ilmu Ternak Vet. 2014;19:184-92. https://doi. org/10.14334/jitv.v19i3.1081

23. Adrizal A, Fakhri S, Murni R, Yatno Y, Maranata T, Asby S, et al. Cassava meaf meal inclusion in palm kernel meal diet could improve egg yolk color in post-molted native laying hens. In: The 5th International Seminar on Tropical Animal Production; 2010; Yogyakarta; Indonesia. p. 325-31.

24. Navarro-Villa A, Mica JH, de los Mozos J, den Hartog LA, García-Ruiz AI. Nutritional dietary supplements to reduce the incidence of fatty liver syndrome in laying hens and the use of spectrophotometry to predict liver fat content. J Appl Poult Res. 2019;28:435-46. https://doi. org/10.3382/japr/pfz005

25. Gao X, Liu P, Wu C, Wang T, Liu G, Cao H, et al. Effects of fatty liver hemorrhagic syndrome on the AMP-activated protein kinase signaling pathway in laying hens. Poult Sci. 2019;98:2201-10. https://doi.org/10.3382/ps/pey586

26. Akiba Y, Matsumoto T. Effects of force-feeding and dietary cellulose on liver lipid accumulation and lipid composition of liver and plasma in growing chicks. J Nutr. 1978;108:739-48. https://doi.org/10.1093/jn/108.5.739

27. Akiba Y, Matsumoto T. Effects of dietary fibers on lipid metabolism in liver and adipose tissue 
in chicks.J Nutr. 1982;112:1577-85. https://doi.org/10.1093/jn/112.8.1577

28. Smith A, Rose SP, Wells RG, Pirgozliev V. The effect of changing the excreta moisture of caged laying hens on the excreta and microbial contamination of their egg shells. Br Poult Sci. 2000;41:168-73. https://doi.org/10.1080/713654903

29. Jiménez-Moreno E, de Coca-Sinova A, González-Alvarado JM, Mateos GG. Inclusion of insoluble fiber sources in mash or pellet diets for young broilers. 1. Effects on growth performance and water intake. Poult Sci. 2016;95:41-52. https://doi.org/10.3382/ps/pev309

30. Jiménez-Moreno E, Frikha M, de Coca-Sinova A, García J, Mateos GG. Oat hulls and sugar beet pulp in diets for broilers 1. Effects on growth performance and nutrient digestibility. Anim Feed Sci Technol.2013;182:33-43. https://doi.org/10.1016/j.anifeedsci.2013.03.011 